\title{
A função da retórica politica de Antonio Vieira na Restauração: uma análise do sermão de Santo Antônio
}

\author{
The role of Antonio Vieira's political rhetoric in the \\ Restoration: A St. Anthony's Sermon analysis
}

Raphael Silva Fagundes ${ }^{1}$

\begin{abstract}
Resumo
O artigo defende a tese de que na cultura do Barroco a persuasão seria o carrochefe das monarquias absolutistas no projeto de manutenção do poder. Analisando as estratégias retóricas do padre Antonio Vieira, buscamos compreender como os sermões do jesuíta (em especial o Sermão de Santo Antonio, pregado em 1642, na Igreja das Chagas de Lisboa) agiram para a consolidação do rei D. João IV, que acabara de chegar ao trono com o advento da Restauração. O objetivo é compreender a utilidade da retórica para o fortalecimento dos reis, promovendo uma articulação entre a fé religiosa e a conjuntura política.
\end{abstract}

Palavras-chaves: Antonio Vieira; Retórica; Restauração; Barroco.

\section{Abstract}

The article defends the thesis that in the culture of the Baroque persuasion would be the flagship of absolute monarchies in power. Analyzing Father Antonio Vieira's rhetorical strategies, we tried to understand how the sermons of that Jesuit (especially the Sermão de Santo Antonio, preached in 1642, in the Igreja das Chagas de Lisboa) acted for the king D. João IV 's consolidation, who had just come to the throne with the advent of the Restauração. The goal is to understand the utility of rhetoric for the strengthening of kings, promoting a link between religious faith and political circumstances.

Keywords: Antonio Vieira; Rhetoric; Restoration; Baroque.

\footnotetext{
${ }^{1}$ Doutorando do Programa de Pós-Graduação em História Política da UERJ.
} 
Religare, ISSN: 19826605, v.15, n.1, agosto de 2018, p.324-350.

\section{Introdução}

Segundo Quentin Skinner (1996, p. 49), as bases por onde se desenvolveu o pensamento político renascentista estão submetidas a duas tradições: uma é o estudo da retórica, que desde a fundação das universidades na Itália, constituiria em um tópico de ensino fundamental ao lado da medicina e do direito; a outra é a escolástica, que partiu da França para a Itália nos finais do século XIII. Destas duas correntes irão nascer os humanistas dos Quatrocentos. É também delas que surgirão diversas ordens religiosas inclusive a Companhia de Jesus na qual está inserido o padre Antonio Vieira. Esta relação entre escolástica e retórica será a quintessência da oratória do pregador inaciano, onde da primeira utiliza os mistérios bíblicos, quanto da segunda a habilidade persuasiva de seus sermões. Estes elementos estão claros no "Sermão da Sexagésima" pregado na capela real em 1655:

Fazer pouco fruto a palavra de Deus no Mundo, pode proceder de um de três princípios: ou da parte do pregador, ou da parte do ouvinte, ou da parte de Deus. Para uma alma se converter por meio de um sermão, há-de haver três concursos: há-de concorrer o pregador com a doutrina, persuadindo; há-de concorrer o ouvinte com o entendimento, percebendo; há-de concorrer Deus com a graça, alumiando (VIEIRA, 1998c).

Nesta passagem identificam-se três provas do discurso (ethos, pathos e logos) a maneira de Aristóteles, sendo o logos (o "próprio discurso, pelo que ele demonstra ou parece demonstrar" (ARISTÓTELES, s/d., p. 34) substituído pela Graça. Havia a crença comum da época de que a competência oratória era um dom da Graça e, esta, por sua vez, deveria manifestar-se no próprio discurso.

As transformações mentais provocadas na cultura ocidental a partir da Idade Média iriam influenciar diretamente na estrutura da fala. Aristóteles afirmava que é "pelo discurso que persuadimos, sempre que demonstramos a verdade ou o que parece ser a verdade, de acordo com o que, sobre cada assunto, é suscetível de persuadir" (ARISTÓTELES, s/d, 35). Portanto, a partir 
Religare, ISSN: 19826605, v.15, n.1, agosto de 2018, p.324-350.

do momento em que a argumentação se apoiava na prova incontestável, para os medievos a única fonte da Verdade era a Bíblia. Essa foi a chave para a adaptação da oratória clássica à prédica cristã medieval.

Santo Agostinho foi quem apreendeu a importância da retórica para a atividade prédica. Jesus falava através de fábulas, por exemplo, porque em seu tempo, era a forma mais usual e popular de disseminar uma ideia. Isto é, como explicou a professora Maria do Amparo Maleval, "na Bíblia se encontram exemplos de pregadores, teorizações sobre a prédica e também técnicas retóricas diversas, sendo abundantes as figuras e/ou tropos reconhecidos desde os primeiros séculos cristãos e no medievo por autores como Santo Ambrósio, Santo Agostinho..." (MALEVAL, 2010, p. 100)

Textos como os de Gregório Magno, o Cura pastoralis, de Santo Isidoro de Sevilha, a Etymologiarum, foram fundamentais para instruir oradores nas artes da retórica fundindo a tradição judaico-cristã à oratória clássica. Dessa fusão surgiram as artes praedicandi de onde emanaram uma pluralidade de sermões que visavam ensinar sobre a moral católica. Exemplos eram extraídos ao mesmo tempo dos profetas bíblicos e dos tratadistas clássicos como Aristóteles, Cícero e Quintiliano construindo, enfim, fórmulas para serem usadas nos sermões pregados nas mais diversas circunstâncias (MALEVAL, 2010, p. 120).

Vieira, além de herdeiro dessa artes praedicanti, compartilhava da linguagem política da contrarreforma influenciada pelo humanismo e pelo neotomismo que, por sua vez, ganharam fôlego com os jesuítas espanhóis Francisco Suárez e Luís de Molina que, entre outras atividades, foram também professores em Portugal, o primeiro na Universidade de Coimbra e o segundo em Évora (PÉCORA, 1994, p. 73). Essa linguagem política, que se valia de citações de autores clássicos e da fé na atuação do homem no mundo criado por Deus, refutava, além do luteranismo, Maquiavel, por este ter introduzido uma "nova moralidade política" que se apresentava adversa ao catolicismo. (SKINNER, 1996, p. 449) Além disso, a linguagem política adotado pelos jesuítas contribuiu para "transformar o púlpito em poltrona de deputado ou cadeira de 
Religare, ISSN: 19826605, v.15, n.1, agosto de 2018, p.324-350.

conselheiro e mais de uma vez em tribuna de causídico" (CIDADE, s/d, pp. 4243), como destacou Hernani Cidade sobre o ímpeto político de Vieira.

O professor Alcir Pécora (2000, p. 11-13) observa que a oratória dos padres jesuítas supõe a projeção permanente de Deus nas formas de existência do universo criado, ou seja, uma retórica que evidenciava a presença de Deus em tudo, lendo acontecimentos históricos ou naturais como uma mensagem providencial e, passagens bíblicas, como acontecimentos históricos e naturais. Pécora chama essa maneira de pregar de "modelo sacramental", que, não obstante, no caso de Vieira, também apresenta uma dimensão política, ao usar elementos ligados a comunhão sob a égide de Cristo ao mesmo tempo em que defendia a égide do Estado cristão português para a proteção da prosperidade.

Os sermões do período da Restauração (1640-1668) devem ser concebidos, de acordo com João Francisco Marques, “dentro de uma mundividência providencialista e de um messianismo exaltante, [que] estimulam, pela sacralização, toda a atuação patriótica necessária, para se enfrentar realidades imediatas". Sendo assim, o autor concluiu que "a expressão retórica é um dado cultural, é uma linguagem situada no tempo", de maneira que tais sermões visavam "não assegurar a perpetuação, no futuro, do momento vivido, mas levar à ação" (MARQUES, 1983, p. 20). O objetivo dos sermões era persuadir de uma perspectiva política e teológica, por isso que Pécora os apreende em uma unidade teológica-retórica-política.

Vieira se vale do que Antonio J. Saraiva denomina de "discurso engenhoso". O orador extrai todo o significado do significante dando a palavra um sentido conivente aos seus interesses, isto é, do que se quer persuadir. De acordo com Saraiva, Vieira acreditava que sua "alquimia verbal e a construção de conceitos eram meios para persuadir o ouvinte de uma verdade ou para constrangê-lo a uma ação" (SARAIVA, 1980, p. 122). Todas as coisas descritas pelo pregador adquirem um sentido sagrado, tornando-se, por seu turno, incontestáveis. 
Religare, ISSN: 19826605, v.15, n.1, agosto de 2018, p.324-350.

Já a professora Margarida Vieira Mendes, analisa a obra de Vieira por outro ângulo. No seu entender, a atividade do padre inaciano tanto oral quanto escrita, "trabalha no sentido de construir uma imagem" (MENDES, 1989, p. 16). O ethos era a principal prova do orador subjugando as outras provas retóricas na composição de um argumento. Incorporando a imagem de um profeta bíblico em muitos casos, Vieira se via em cena cumprindo um papel designado pela Providência a favor de Portugal.

Em relação aos estudos que focalizam a retórica de Vieira também é de suma importância a abordagem de Valmir Francisco Muraro sobre o aspecto utópico do padre inaciano. Sua pesquisa compreende a imagem do Quinto Império através de uma retórica que se apóia em "argumentos localizados nas Escrituras", em textos de profetas portugueses e nos acontecimentos políticos. Muraro conclui que toda a argumentação de Vieira "apontava para um alvo futuro: 'o Quito Império'”' governado por D. João IV (MURARO, 2003, p. 20). Deste modo, antes de analisarmos o "Sermão de Santo Antonio", é preciso compreender a relevância da retórica em prol das monarquias barrocas do século XVII.

\section{O barroco como uma cultura persuasiva}

No "Sermão Histórico e panegírico nos anos da Rainha D. Maria Francisca de Sabóia", de 1668, Vieira diz que a função da esposa é aconselhar, e a do homem mandar. Para que haja graça no governo de D. Pedro II que acabara de se instalar, era necessário que a Rainha usasse de sua graça para sugerir. Esta palavra, para o padre inaciano, significava uma série de coisas e, entre elas, podemos encontrar a persuasão, fenômeno da linguagem que recebeu um grande destaque na cultura barroca:

Nas cláusulas desta sentença distingue Cristo dois ofícios, um seu, outro do Espírito Santo. O primeiro é mandar, o segundo é sugerir. Ninguém pode mandar só, se houver de mandar como 
Religare, ISSN: 19826605, v.15, n.1, agosto de 2018, p.324-350.

convém. Ao lado do ofício de mandar, deve andar sempre o ofício de sugerir, ou como companheiro, ou como instrumento inseparável. A obrigação e exercício deste segundo e tão importante ofício, é o que significa a mesma palavra sugerir, que vem a ser - lembrar, advertir, inspirar, aconselhar, conferir, persuadir, espertar, instar (VIEIRA, 1668, p. 29).

Certamente, precisamos compreender que "os Padres da Igreja primitiva adaptaram a Retórica antiga, via Cícero e Quintiliano, como modo de formar, às categorias da hermenêutica, método de interpretar, coisa que a Idade Média repetiu essencialmente". João Adolfo Hansen afirma que tais padres criaram a "alegoria dos teólogos", um método de interpretar os eventos do mundo por meio das Escrituras Sagradas. A Retórica antiga usava a alegoria como um simbolismo linguístico; os padres da Idade Média a adaptaram, "pensando-a como simbolismo linguístico revelador de um simbolismo natural, das coisas, escrito desde sempre por Deus na Bíblia e no mundo" (HANSEN, 2006, p. 12).

Essa "alegoria dos teólogos" é proveniente da "alegoria dos poetas", essencialmente linguística, vinculada apenas à expressão, não a interpretação do mundo. Aliás, como demonstrou Georges Duby, a arte oratória era ensinada na Idade Média pelos "modos de elocução que apenas se podem aprender nos poetas" (DUBY, 1967, p. 68). Desta forma, com os padres, essa herança linguística adquire um fim hermenêutico.

Contudo, é por meio desta eloquência que se realiza o controle sobre o tempo, pois é através dela que são interpretados os acontecimentos; acomodados os feitos e as profecias antigas ao contexto cultural e político do sermão; enfim, é por suas alegorias linguísticas que se evidencia a essência de Deus nas coisas de forma atemporal. Por isso, o uso de uma alegoria bíblica é intencional, segundo Hansen, e está de acordo com o gênero e as circunstâncias do discurso (HANSEN, 2006, p. 09).

Qualquer evento que venha a acontecer, uma enchente, uma tempestade, uma mudança de poder, uma invasão, guerras, períodos de paz, tudo é interpretado por meio de passagens bíblicas alegoricamente articuladas aos 
Religare, ISSN: 19826605, v.15, n.1, agosto de 2018, p.324-350.

interesses do momento, revelando a presença de Deus e o controle da Igreja (grande gestora de tais alegorias) sobre o tempo. Isso pode ser visto no parecer do "Sermão Histórico e panegírico nos anos da Rainha D. Maria Francisca de Sabóia" realizado pela Inquisição. Este sermão deveria ser pregado na capela real, mas por motivo de saúde Vieira não pode comparecer. Várias passagens bíblicas são citadas destacando as mulheres que aconselhavam os seus maridos, mas na verdade era uma jogada política clara, já que D. Maria era uma princesa francesa, uma união desejada há muito pela diplomacia do padre Antonio Vieira para combater a poderosa Espanha. Era 1668, a independência de Portugal já fora reconhecida pelos Habsburgos, mas um aliado como a França era muito importante. Sendo assim, podemos observar os comentários do Santo Ofício sobre o papel (termo usado para designar os sermões impressos): “...por serem os discursos que contém tirados do Evangelho com grande engenho, provados com grandes razões, e muitos lugares das Sagradas Escrituras, que o fazem muito merecedor de divulgar-se pela estampa" (VIEIRA, 1668, p. 04). A relação da princesa francesa com o rei D. Pedro II possui comprovação bíblica e por isso é legítima.

Os acontecimentos do passado ligam-se aos do presente, que desembocarão em um futuro já inscrito. Um fenômeno que não era meramente retórico, como será no século XIX, mas epistemológico. É nesta epistemologia que uma obra como a História do Futuro de Vieira foi possível ser escrita. As contradições do meio levam ao uso de um determinado tipo de alegoria bíblica, e esta, por sua vez, irá intervir e codificar o sentido destas contradições. Sendo assim, a alegoria não era mais um ornamento da arte retórica, um mero enfeite, como afirmava Quintiliano, pelo contrário, ela tinha uma função no discurso. Os Padres a pensavam como revelação dos mistérios divinos (HANSEN, 2006, p. 30). Até a própria persuasão, elemento último da arte retórica, tinha origens sobrenaturais para tais homens, "pois sem ela Lúcifer não teria conseguido seduzir os outros anjos que o acompanharam na Queda" (HANSEN, 2006, p. 59) diz Boncompagno de Signa em 1235. 
Religare, ISSN: 19826605, v.15, n.1, agosto de 2018, p.324-350.

Se a eloquência tinha um fim divino, ela estaria a serviço dos reis cristãos. Nesta questão, em particular, houve um grande investimento retórico por parte de Felipe II para legitimar o domínio sobre Portugal, no período conhecido como a União Ibérica. Em um momento em que aumentava a desaprovação de seu governo, o rei católico investiu na presença de sua imagem no vasto território que dominava durante o século XVI. A imprensa foi fundamental nesta tarefa. Imprimiram-se as antigas leis que legitimavam a união das coroas de Portugal e Castella. Além disso, foram criadas pela ordem real as cartas generales para plegarias, um documento que determinava que uma propaganda do rei católico deveria ser feita em meio a solenidade litúrgica nas igrejas de Castella. Era um sistema rígido em que três horas durante a manhã e três durante a tarde eram dedicadas à oração ao monarca. Segundo Fernando Bouza Alvarez, “la figura monárquica saldría reforzada después de ser continuamente consagrada" (BOUZA, 1998, p. 147).

Durante as missas, os sermões dos padres eram recheados de passagens bíblicas que legitimavam o poder do monarca Habsburgo. Em 1571 o principal ministro de Felipe II, o cardeal Diego de Espinosa, compara a conquista de Lepanto com a destruição do exército do faraó no Mar Vermelho. Já o frei Hernando Del Castillo, em uma perspectiva mais voltada para o passado profano, entendia que "uniendo el reyno de Portugal al de Castilla [Don Felipe] será el mayor Rey Del mundo (...) porque se los Romanos con enseñorear solo el mar Mediterráneo enseñorearon el mundo" (PARKER, 2002, p. 325). Deste modo, podemos perceber que era comum o empenho dos membros da Igreja fomentar retoricamente a atitude dos seus reis.

A retórica estava presente nas diversas formas de manifestação de poder neste mundo ibérico. Em sua tese de doutorado, Ana Isabel López (2008, p. 322323) destaca as tensões e conflitos travados entre o Santo Ofício e as instituições do governo ao longo da União Ibérica e nos primeiros anos dos Bragança. Nos autos de fé um sermão era pronunciado. No exórdio, era necessário que o pregador realizasse a captatio benevolentiae, estratégia argumentativa 
Religare, ISSN: 19826605, v.15, n.1, agosto de 2018, p.324-350.

apresentada na Retórica à Herenio, obra que alguns atribuem a Cícero. É nesse instante que se deve usar de argumentos para prender a atenção do auditório, torná-lo benevolente. O conflito era quem deveria ser citado neste momento do discurso, o inquisidor-geral ou o vice-rei. O lugar temporal no discurso representava a expressão do poder que os agentes citados desempenhavam na cerimônia religiosa.

Este modelo permaneceu na tradição da Igreja e se fortaleceu na cultura do Barroco, tendo influência direta nos discursos teológico-retórico-políticos do Padre Antônio Vieira. José Antonio Maravall descreve que “a retórica e o uso variadíssimo de seus múltiplos recursos" significam muito "nesse momento cultural”. Segundo o autor, "a passagem da retórica para o primeiro plano entre as artes da expressão [...] e o retorno à retórica aristotélica são fenômenos ligados ao desenvolvimento europeu do Barroco" (MARAVALL, 2009, p. 334). A retórica, deste modo, foi um dos instrumentos utilizados pelas monarquias absolutistas para restaurar a ordem social medievalizante. Podemos chegar à conclusão de que o Barroco se pautou em uma produção cultural de base persuasiva.

No século XVII havia um aspecto ao mesmo tempo religioso e cultural que interferiu diretamente na atividade retórica: o mistério. Michel de Certeau destaca que este elemento do oculto comandava "o 'estilo', a retórica, quer dizer, esta arte de falar, onde a alegoria representa um papel decisivo e que consiste em dizer uma coisa dizendo outra coisa". Os seiscentos era um mundo em declínio em que a retórica teria uma função extremamente importante. É por esta ótica que Certeau compreende o grande investimento nesta arte: "uma sociedade inteira diz o que está construindo, com as representações do que está perdendo" (CERTEAU, 2008, p. 140).

Outro aspecto que podemos apreender da retórica deste período é o que demonstra Giulio Carlo Argan. Segundo o autor, o empenho da arte barroca era transformar o ideal religioso em um ideal burguês, ou seja, "convertirlo en norma para la vida social y política" (ARGAN, 2010, p. 112). Segundo Argan, os 
Religare, ISSN: 19826605, v.15, n.1, agosto de 2018, p.324-350.

artistas se apoderaram da teoria dos afetos do segundo livro da Retórica de Aristóteles como "condición fundamental para que el arte sea capaz de cumplir su tarea de convencer". Já no limiar de seu artigo, o autor deixa bem claro que “en contraste con el neoplatonismo de Miguel Ángel, el barroco significa una comprobación del pensamiento aristotélico, no sólo respecto a la ya investigada influencia de la Poética, sino, sobre todo, en cuanto a la Retórica" (ARGAN, 2010, p. 112).

Essa função da retórica - principalmente nos sermões - no circuito político e cultural levou o padre Antonio Vieira a cometer em 6 de janeiro de 1641 uma das maiores gafes de sua trajetória política (VAINFAS, 2011, p. 86). Como a notícia da Restauração, movimento que pôs fim ao domínio espanhol em Portugal, demorou um mês para chegar à colônia portuguesa na América, Vieira, no "Sermão do Dia de Reis", exalta a dinastia filipina - como dizia o protocolo - sem saber do acontecido em Portugal em 15 de dezembro do ano anterior. Proferiu um discurso que negava tanto o bandarrismo quanto o sebastianismo, afirmando que não havia rei encoberto algum. Sabemos que mais tarde, Vieira muda totalmente o seu posicionamento atribuindo características sebastianistas ao rei D. João IV criando o que muitos chamarão de joanismo. Ainda no mesmo ano, o vice-rei do Brasil, o marquês de Montalvão, pai de fidalgos fieis à Felipe IV, como D. Pedro de Mascarenhas, recebe cartas deste que buscavam persuadi-lo a se aliar a causa do rei espanhol. No entanto, por ter a maioria dos seus bens assentes em Portugal preferiu se aliar ao rei português e manda uma delegação para o reino com seu filho D. Fernando de Mascarenhas acompanhado de dois jesuítas, o padre Antonio Vieira e o padre Simão de Vasconcelos (COSTA e CUNHA, 2006, p. 114). O que dará início a grande jornada política de Vieira na Europa.

Ao desembarcar em Peniche, o povo revoltado com os filhos e esposa de Montalvão, vistos como traidores, recebe a delegação com pedradas em meio a um motim. D. Fernando é ferido na cabeça e rapidamente foi recolhido com os padres a uma prisão, "sem dúvida de os ter a bom recado" (LISBOA, s/d, p. 20- 
Religare, ISSN: 19826605, v.15, n.1, agosto de 2018, p.324-350.

21). Após a chegada em Portugal, Vieira envolve-se em diferenciadas contendas políticas nas quais os seus sermões se mostravam atos de fala. Para lidar com tais imbróglios, Vieira teve que investir com vigor em uma retórica da unidade, que também tinha o objetivo de reunir os estamentos sociais para a conservação do reino restaurado.

Nesta questão, diversos juristas se envolveram. Antonio Carvalho de Parada escreve a Arte de Reinar em 1641, Antonio Pais Viegas o Manifesto do Reyno de Portugal, João Pinto Ribeiro a Uzurpação, Retenção, Restauração de Portugal em 1642. Houve também aqueles que se dedicaram a espalhar pela Europa a legitimidade da Restauração, principalmente em contraposição aos argumentos filipistas de Juan Caramuel Lobkowitz, um letrado que teve sua obra, Respuesta al Manifiesto del Reyno de Portugal publicada em 1641 na cidade de Antuérpia. O lado português contava com Antonio de Sousa de Macedo e Manuel Fernandes Vila Real. Em Paris saiu em 1643 Anticaramuel o defensa del Manifesto del Reyno de Portugal de Vila Real e, em Londres, Juan Caramuel Lobkowitz, Religioso de la orden de Cistere Abbad de Melrosa, etc; convencido em su Libro intitulado "Philipous prudens Caroli V Imper. Filiu Lusitaneae etc" de Macedo referente a uma outra obra do erudito defensor da causa de Felipe IV. Vale dizer que Sousa de Macedo travou discussões jurídicas com o próprio rei Carlos I sobre a legitimidade de D. João IV no trono português (COSTA e CUNHA, 2006, p. 162).

Vieira e diversos jesuítas ficaram ao lado deste grupo de letrados, incluindo aí o padre jesuíta João de Vasconcelos que, sob o pseudônimo de Gregório de Almeida, escreve a famosa Restauração de Portugal Prodigiosa de 1643 (COSTA e CUNHA, 2006, p. 158). Travou-se uma "guerra de imprensa" em que Antonio Vieira teve lugar importante com as obras História do Futuro e a Clavis Prophetarum. Além disso, há um destaque para o pintor Avelar Rebelo, o que mais retratou o rei D. João IV. Em suma, em todas estas manifestações podemos encontrar elementos da cultura do barroco e do imenso poder persuasivo que carregavam. 
Religare, ISSN: 19826605, v.15, n.1, agosto de 2018, p.324-350.

Vieira viaja grande parte da Europa com missões oficiais e secretas. Propõe o casamento do infante D. Teodósio com a princesa da França, Anne Marie d'Orleáns tendo a abdicação de D. João IV em favor do filho. Inclusive a ideia de Vieira era de que D. João iria reinar no Brasil e D. Teodósio em Portugal. Tudo era para conseguir aliados na luta contra os espanhóis. Conseguiu fazer da Inquisição portuguesa sua inimiga, pois não concordavam com os projetos de Vieira em relação aos judeus, principalmente com o banqueiro Duarte da Silva e o principal agente do inaciano e do rei, Manuel Fernandes Villa Real. Os dois foram presos pela Inquisição.

A partir dos anos de 1649 Vieira começa a perder sua força política em decorrência da prisão destes judeus. A facção contrária aos pensamentos de Vieira no interior da Cia de Jesus entra em contato com o Papa para expulsá-lo da ordem, mas Vieira, amigo íntimo do rei, consegue negociar sua ida para o Maranhão, prefere não sair da ordem devido a sua influência no contexto português (LISBOA, s/d, p. 160). No sermão de São Roque de 1652 deixa claro que mesmo sendo protegido pelo rei não foi possível se manter na corte: "não basta só ter a graça do príncipe supremo, se não alcança também a dos que lhe assistem" (VIEIRA, 1998d). Mas antes de retornar a colônia tem uma última missão em Roma em 1650 cuja parte secreta era casar os herdeiros das coroas de Portugal e Espanha. Um delírio, segundo Ronaldo Vainfas (2011, p. 189).

No “Sermão da Quarta Dominga da Quaresma", pregado na capela real em 1655, antes de retornar ao Maranhão pela segunda vez, Vieira deixa claro que fugiu, isto é, foi forçado a sair. No entanto, usa diversos exemplos de filósofos e personagens bíblicos que provam que é importante fugir dos homens. Além disso, infla o seu ethos relacionando sua vida com a de Cristo que fugiu para o deserto:

Ora, eu que neste lugar fiz antigamente alguns sermões de corte, quisera hoje fazer um sermão de deserto. Bem creio que será pregar em deserto, mas será pregar. Vós, Senhor, que tentado do demônio o vencestes em um deserto, e aplaudido dos homens 
Religare, ISSN: 19826605, v.15, n.1, agosto de 2018, p.324-350.

fugistes deles para outro, sede servido de me assistir neste assunto com vossa mesma soledade, para que haja quem queira fugir de si para vós, e neste monte, onde estais tão só, viver só por só convosco (VIEIRA, 1998b).

Foi claramente um período em que Vieira resolve combater os poderosos. Para dar mais força aos seus argumentos e erguer sua imagem como um indivíduo que segue as mensagens e atitudes dos profetas, citará o profeta Amós, santo Antônio e o próprio Jesus para legitimar sua volta à colônia, equiparada aos desertos desbravados, com a proteção de Deus, por estas figuras santas:

É doutrina expressa de Deus pelo profeta Amós, a qual, como servia para aqueles tempos, pode também servir para outros: Odio habuerunt corripientem in porta, et loquentem perfecte abominatisunt. Ideo prudens in tempore illo tacebit, quia tempus malus est (Am. 5, 10.13): Chegou a corrupção dos costumes a tal estado - diz o profeta - que os poderosos têm ódio a quem repreende suas injustiças, e abominam a quem lhes fala verdade, e nos tais casos o que deve fazer o prudente pregador é calar, porque ainda que a doutrina seja boa, o tempo é mau: Prudens in tempore illo tacebit, quia tempus malum est. Prudentemente fez logo o grande Antônio em antepor o silêncio do seu deserto à pregação da cabeça do mundo, porque no mundo não podia colher fruto para os outros, e no deserto podia frutificar para si. Enfim, fez Antônio então como Cristo hoje, que podendo pregar às turbas, fugiu delas: Fugit (VIEIRA, 1998b, grifo do autor).

É nesse turbilhão de posicionamentos que os sermões do padre Antonio Vieira se encaixam voltados, em essência, por meio de uma supervalorização das antíteses e da virtuosidade sagrada do orador, para a unidade católica sob a égide do rei que liderará o Quinto Império, D. João IV. Sua pregação dos anos 1640 estava repleta de signos que buscavam representar este profetismo político que se fortalece ao longo dos anos 1650 e 1660. Este foi o principal motivo de seu confinamento pela Inquisição em $1^{\circ}$ de outubro de 1665 depois de ter arrumado uma grande confusão no Maranhão sendo expulso pelos colonos que defendiam o cativeiro indígena. Personagens bíblicos, acontecimentos sagrados, 
Religare, ISSN: 19826605, v.15, n.1, agosto de 2018, p.324-350.

hagiografias de santos se misturam às atitudes da Coroa portuguesa recémrestaurada que precisava convencer os que se posicionavam contrários aos rumos do governo. Mas esta eloquência, de base humanista e escolástica, que visa a propagação de projetos políticos, irá sofrer impactos devido às transformações epistemológicas e na concepção de tempo do mundo ocidental.

\section{O sermão de Santo Antonio}

Como foi possível observar através de alguns sermões que usamos para situar Vieira em seu contexto político e cultural, o objetivo de toda pregação do padre inaciano era a persuasão, transmitir uma mensagem com um conteúdo sagrado ordinário. Portanto, iremos agora nos concentrar em um sermão específico: o "Sermão de Santo Antônio".

Pregado na Igreja das Chagas de Lisboa em 1642, o "Sermão de Santo Antônio" chama todos os estados que compunham a sociedade portuguesa para a "conservação" do Estado independente. Tal sermão precedeu a convocação das cortes pelo rei D. João IV a fim de rever a questão da carga tributária. A discussão foi estabelecida ao redor da décima, um novo modelo de imposto para angariar recursos na luta contra Castela. Mas o imposto precisava ser visto como um "donativo" e o sermão pregado por Vieira às vésperas do encontro irá tratar claramente deste tema (MAGALHÃES, 2006, p. 93).

Mas por que Santo Antonio? Santo Antonio era um santo português canonizado por Roma menos de um ano após sua morte em 13 de junho de 1231. A ele foram atribuídos diversos feitos milagrosos como ressurreições, controle das forças da natureza; "curas de toda sorte de enfermidades; converteu um sapo em um frango e depois outro frango em sapo, a fim de confundir um heresiarca; fez um recém-nascido falar para defender a honra de sua mãe" etc. A partir dos Seiscentos, o santo passou a ser militar e era evocado como "recuperador de escravos prófugos no Brasil" (MOTT, 1996, p. 115-116). Era considerado um perfeito procurador de corte por duas qualidades: “ser fiel, 
Religare, ISSN: 19826605, v.15, n.1, agosto de 2018, p.324-350.

e ser estadista". É a partir dos atributos dados ao santo que a conservação do Estado português seria possível, isto é, todo português deveria ser fiel e estadista. Por meio da atividade retórica, Vieira estabelece uma unidade entre o santo e os ouvintes, recheando a cena comunicativa de sacralidade.

Santo Antonio é conhecido por recuperar coisas perdidas e Castela fazia preces a ele com esta finalidade. Por seu turno, Vieira afirmava que para os seus compatriotas, Santo Antonio tinha um outro fim, conservar. "Santo Antonio, para os estrangeiros, é recuperador do perdido; para com os seus é conservador do que se pode perder" (VIEIRA, 1995, p. 06). Em seguida, Vieira diz que o santo ressuscitava os mortos, no entanto, somente estranhos. "Aos estranhos ressuscitou-os depois de perderem a vida, a seu pai defendeu-lhe a vida, para que não chegasse a perdê-la; aos estranhos remedeia, mas ao seu sangue preserva". O próprio Cristo agia da mesma forma: "a todos os homens geralmente livrou-os da morte do pecado, depois de incorrerem nele, mas sua Mãe preservou-a”. Depois conclui: “Assim fez Santo Antonio" (VIEIRA, 1995, p. 07). Assim os portugueses deveriam fazer o mesmo, preservar o que amam, o que estava próximo. As figuras do pai e da mãe foram configuradas na pátria, no reino independente de Portugal que deveria, com o auxílio de Santo Antonio, ser preservado. Vieira manipula o pathos, a emoção dos ouvintes ao instigar sentimentos trazendo a tona a imagem dos pais assemelhando a pátria. A unidade era uma questão sagrada.

Mas convencer seus ouvintes desta questão não foi uma tarefa fácil. Inicialmente, ainda no preâmbulo de seu sermão, o padre destacou que as palavras que iria proferir não eram dele, mas as do próprio santo: "Como tal dirá o santo hoje seu parecer a respeito da conservação do reino, e esta será a matéria do sermão. Santo Antonio é o que há de pregar, e não eu". Mas como seus ouvintes iriam perceber isto? O próprio padre nos dá a resposta: "Mas como eu sou o que hei de falar, para que o discurso pareça de Santo Antonio, cujo é, e não meu, muita graça me é necessária, Ave Maria". Ou seja, ele 
Religare, ISSN: 19826605, v.15, n.1, agosto de 2018, p.324-350.

conseguirá ser eloquente através da graça. Aqui é o ethos, a imagem do orador que é sacralizada assemelhando-se ao santo e sendo tocado pela graça.

Este é um fenômeno da retoricidade sacra. Vieira não quer se mostrar como um indivíduo que está ali com o objetivo de persuadir, pois as palavras sagradas não precisam de persuasão, ou melhor, ninguém precisa ser persuadido da verdade. Isso nos remete às palavras de Paulo em sua Primeira Epístola aos Coríntios: "A minha linguagem e a minha pregação não consistiram em palavras persuasivas de sabedoria, mas em demonstração do Espírito e de poder" (I Cor, 2, 4)

Aqui o ethos do actante, isto é, do sujeito que se apresenta como o enunciador, é o cume do argumento. É a prova irrefutável. Vieira tenta sempre criar argumentos de modo monologal, não abrindo espaço para argumentos contrários, pois joga com o valor mais alto de seu tempo: a fé católica. Promovendo o que Alcir Pécora (2000, p. 11-13) irá chamar de modelo sacramental, Vieira se vale da estratégia aristotélica que vê no ethos uma das provas mais eficazes do procedimento retórico (PLATIN, 2008, p. 112).

O padre de fato concebia a retórica como algo divino. Uma técnica usada até mesmo pelos mortos. No primeiro parágrafo, ao discorrer sobre a matéria do sermão, mostra a frase Vos estis sal terrae. Segundo Vieira, a exemplo de Cristo, S. Antonio repete estas palavras aconselhando os portugueses. Imortaliza o exemplum como uma técnica fundamental no procedimento retórico ao afirmar que tal estratégia é um ingrediente fundamental para os que habitam o outro mundo:

E ninguém me diga que disse estas palavras [Vos estis sal terrae] Cristo a Santo Antonio, e não Santo Antonio a nós, porque, como a retórica dos do outro mundo são os exemplos, e o que obraram Cristo a Santo Antonio o que foi, é dizer-nos Santo Antonio o que devemos ser (VIEIRA, 1995, p. 08).

É estabelecida uma relação entre os portugueses e os seres do outro mundo; uma continuidade, cujo intermediário é o próprio santo. Cristo disse a 
Religare, ISSN: 19826605, v.15, n.1, agosto de 2018, p.324-350.

Santo Antonio, este disse o mesmo aos portugueses, deste modo, Vieira mistura os personagens colocando-os na mesma esfera do discurso, pois assim como o Santo ouviu Cristo, o povo português deve ouvi-lo.

Para além dessa questão, é preciso observar o fato que Vieira construiu o seu ethos discursivo sobre a imagem do santo. Não é o nome que é apenas coincidência, mas a habilidade com as palavras. De acordo com a professora Maria do Amparo Maleval, "Santo Antonio conheceu e assimilou ou interagiu com a arte retórica da prédica" (MALEVAL, 2010, p. 112). A estrutura dos seus sermões era a mesma consagrada pelas artes praedicandi em geral, que, durante a Idade Média, na esteira das recomendações do monge cistercense Alain (Alão) de Lille, estabeleceu uma fusão entre a oratória clássica com os elementos de retórica encontrados nos santos e profetas das Sagradas Escrituras.

Jesus, de acordo com Marcos 4, 33-34, “com muitas parábolas semelhantes lhes anunciava a palavra, tanto quanto podiam receber", isto é, adaptava-se ao seu auditório, a multidão, como nos ensina Aristóteles, propositalmente (retoricamente), já que "quando, porém estava a sós com os seus discípulos, explicava-lhes tudo". Bons oradores em vida, porque não seriam após a morte, no Paraíso, ao lado do Espírito Santo?

O sal é a principal substância pela qual o padre irá estruturar o seu discurso. Era composto por três elementos diferentes (água, fogo e ar) de extrema utilidade para conservar um quarto elemento: a terra (MAGALHÃES, 2006, p. 95). De acordo com alguns pesquisadores, Vieira acaba por divulgar um certo conhecimento científico ao usar tais elementos em sua eloquência. Conhecimentos sobre o sol, a luz, o movimento circular dos astros e da água estão presentes nos sermões. Segundo Luís Miguel Carolino, a "Ciência surge, portanto, como um suporte do discurso retórico e, logo, subordinada aos objetivos catequéticos do sermão" (CAROLINO, 1997, p. 61). Vieira se valerá deste aspecto da invenção retórica, isto é, deste lugar onde buscará recursos para reforçar seus argumentos. 
Religare, ISSN: 19826605, v.15, n.1, agosto de 2018, p.324-350.

Por outro lado, vale à pena destacar que o sal tinha um papel fulcral na vida econômica portuguesa. Segundo Jean-Fréderic Schaub, o sal era o produto mais importante na exportação lusitana e uma "mercadoria essencial, para não dizer estratégica, na Europa moderna". "As salinas de Aveiro, Setúbal e Alcacer do Sal escoavam uma parte considerável da sua produção para as Províncias Unidas" (SCHAUB, 2001, p. 74). Desde a Idade Média, o sal português era comercializado com os negociantes holandeses. Aliás, a interrupção deste comércio com o advento da União Ibérica gerou muita tensão entre os comerciantes portugueses e a monarquia dos Habsburgo.

Uma alegoria é desenhada pelo padre, como um hábil pintor perante uma tela a lançar tintas. Os portugueses são relacionados aos apóstolos de Cristo, este por semelhança a Santo Antonio. Cristo disse aos seus: "Sois pescadores, apóstolos meus, porque quero que vades pescar por esse mar do mundo; mas advirto-vos que sois também sal, porque quero que pesquies, não para comer, senão para conservar". Esta é a cena propícia para as Grandes Navegações, o orgulho do ser português. Deste modo, diz Vieira:

Senhores meus, já fomos pescadores; ser agora sal é o que resta. Fomos pescadores astutos, fomos pescadores venturosos, aproveitamo-nos da água envolta, lançamos as redes a tempo, e ainda formoso lanço que se fez nunca, não digo nas ribeiras do Tejo, mas quanto rodeiam as praias do Oceano (VIEIRA, 1995, p. 08).

Por meio da semelhança criada pelo discurso que suspende a similitude das situações, os portugueses tornam-se os escolhidos. São os apóstolos de Santo Antonio, como Pedro, Paulo e João foram em outro tempo os de Cristo. E aponta a missão dos portugueses salinizados: "Pescou Portugal o seu reino, pescou Portugal a sua coroa; advirta agora Portugal que não pescou para a comer, senão para a conservar. Foi pescador, seja sal" (VIEIRA, 1995, p. 09).

A semelhança não era um recurso retórico, mas uma epistémê, a maneira de compreender o mundo predominante no século XVI em toda Europa e que se arrasta nos seiscentos lusitanos adentro. Para Michel Foucault, em sua obra 
Religare, ISSN: 19826605, v.15, n.1, agosto de 2018, p.324-350.

As Palavras e as Coisas, a epistémê seria o que age como nexo entre o signo e o que ele indica, o que permite com que os homens desnaturalizem a natureza e dê a ela sentido. De forma bastante polêmica, Foucault afirma que "numa mesma cultura e num dado momento, nunca há mais de uma epistémê, que define as condições de possibilidade de todo o saber" (FOUCAULT, 1990, p. 181). Destaca as formas de interpretação de textos que vigoraram do século XVI ao século XIX, período, conforme mostra sua pesquisa, marcado por grandes mudanças epistemológicas. A primeira destas epistémês foi a semelhança. O mundo só faria sentido através dela. A parecença entre as coisas era feita por meio de figuras como conveniência, emulação, analogia e simpatias. Desta maneira, todas as coisas do mundo poderiam se aproximar. O reino do saber do século XVI é dominado pela semelhança, um modelo de identidade que não respeitava as regras do tempo ou do espaço.

Os hermenêuticos católicos (incluímos aqui o próprio Padre Antonio Vieira) utilizaram deste sistema para compreender os eventos através das situações sagradas descritas na Bíblia. O visível era apenas uma aparência do invisível, ou seja, a manifestação do Ser divino. Deste modo, independente do tempo, as coisas tinham a mesma essência, a mesma pulsão que as tracionava a existir no mundo (FOUCAULT, 1990, p. 45). À tradição da Antiguidade misturava-se ao conhecimento mágico medieval para a compreensão do mundo. "Em outras palavras, Divinatio e Eruditio são uma mesma hermenêutica". "A verdade de todas essas marcas - quer atravessem a natureza, quer se alinhem nos pergaminhos e nas bibliotecas - é em toda a parte a mesma: tão arcaica quanto a instituição de Deus" (FOUCAULT, 1990, p. 50).

O século de Vieira é marcado pelo conflito de duas epistémês. No entender de Michel Foucault, "no começo do século XVII, nesse período que, com razão ou não, se chamou barroco, o pensamento cessa de se mover no elemento da semelhança" (FOUCAULT, 1990, p. 66). Destaca que a similitude, antes usada como forma de saber, é substituída pelo método cartesiano: "a comparação não tem mais como papel revelar a ordenação do mundo; ela se faz 
Religare, ISSN: 19826605, v.15, n.1, agosto de 2018, p.324-350.

segundo a ordem do pensamento e indo naturalmente do simples ao complexo". O século XVII é um século, segundo Foucault, racionalista; "podemos, se não tivermos na cabeça senão conceitos prontos, dizer que o século XVII marca o desaparecimento das velhas crenças supersticiosas ou mágicas e a entrada, enfim, da natureza na ordem científica" (FOUCAULT, 1990, p. 69-70).

No entanto, é preciso destacar que o "século de Descartes é o mesmo século de Bossuet" (FRANÇA, 1997, p. 41). Não podemos dizer que todo o século XVII rompeu com o saber anterior; principalmente quando se trata do mundo Ibérico. O engenho, por exemplo, faculdade específica para o uso da retórica, ganha um grande vigor para desvendar o mistério divino nas coisas. Renato Barilli, no seu estudo bem detalhado acerca da história da retórica, destaca:

É claro que eles reconhecem o papel cada vez mais importante desempenhado pela analítica, forte na faculdade do juízo, cuja tarefa é distinguir, notar as diferenças, isto é, fundamentalmente, dividir e separar, como de resto faz também a prudência. Mas ao lado deste momento dissociador eles salvaguardam o direito do órgão (o engenho) que procura pelo contrário as semelhanças, as parentelas, as afinidades, que não hesita em 'transportar-nos' dum âmbito ao outro (BARILLI, 1979, p. 96).

Vieira claramente revela sua epistémê (para usar o termo foucaultiano) no “Sermão da Segunda Dominga da Quaresma" de 1655: "Mas, para ser figura da glória, não basta só o valor e o preço, senão também a semelhança, porque sem semelhança não pode haver figura" (VIEIRA, 1998b). Esta passagem revela a permanência da epistémê da semelhança como forma de compreender o mundo.

Elementos de caráter científicos, como no caso do sal, eram sacralizados e adaptados à cena de enunciação. O sal é visto como uma situação desconfortável dos estamentos da sociedade portuguesa que devem pagar os tributos para que a monarquia recém-instalada não se desfaça. É uma situação salgada. Todavia, é necessário dosar o sal. Tal substância é necessária para o tempero, mas não pode ser percebido, tem que apenas dar o gosto: “é o 
Religare, ISSN: 19826605, v.15, n.1, agosto de 2018, p.324-350.

preservativo dos preservativos, e o sabor dos sabores". A medida do sal não deve "ofender o gosto". Neste instante, Vieira promove uma ponte para mostrar como é possível tirar algo valioso (se refere ao tributo) sem que aquele que cedeu sinta. Como alegoria usa o ato de Deus ter tirado a costela de Adão enquanto dormia sem que ele sentisse.

Se é necessário para a conservação da pátria, tire-se a carne, tire-se o sangue, tirem-se os ossos, que assim é razão que seja; mas tire-se com tal modo, com tal indústria, com tal suavidade, que os homens não o sintam, nem quase o vejam. Deus tirou a costa de Adão, mas ele não o viu nem o sentiu, e, se o soube, foi por revelação (VIEIRA, 1995, p. 12).

Vieira vai formulando diversos argumentos da mesma natureza para no fim chamar a todos para o pagamento do tributo. Transforma todos os estamentos em portugueses, sem divisão de estado, semelhantes, e usa o próprio Cristo para a construção deste sentimento de igualdade: "A lei de Cristo é uma lei que se estende a todos com igualdade, e que obriga a todos sem privilégio: ao grande e ao pequeno, ao alto e ao baixo, ao rico e ao pobre, a todos mede pela mesma medida" (VIEIRA, 1995, p. 15).

Após estas palavras cria argumentos para mostrar que o tributo é menos pesado quando todos se unem para pagar: "como é peso que sobre todos carrega, a companhia o faz leve" ou "não há tributo mais pesado que o da morte, e, contudo, todos o pagam, e ninguém se queixa, porque é tributo de todos", ou ainda "se amanhece o sol, a todos aquenta, e se chove o céu, a todos molha" (VIEIRA, 1995, p. 16). E sempre há uma autoridade política em seu discurso: "ninguém toma pesadamente o peso que se lhe distribuiu com igualdade - disse o político Cassiodoro" (VIEIRA, 1995, p. 17).

Vieira é cuidadoso ao criar a unidade entre os estados, pois consegue fazer isto sem afetar a posição social de cada um. Desperta o sentimento de caridade dos eclesiásticos, que, por sua vez, tinham o privilégio de não pagar impostos. Mas segundo Vieira é necessário que os homens deixem "de ser o que são, para chegarem a ser o que devem". Para isto, o padre inaciano usa 
Religare, ISSN: 19826605, v.15, n.1, agosto de 2018, p.324-350.

novamente argumentos da Filosofia Natural de que tinha conhecimento para desenvolver tal raciocínio. Ao usar o sal afirma, através de Aristóteles e Plínio, que o sal é formado por três elementos que se unem: o fogo, a água e o ar. Deste modo, o operador argumentativo, "assim como", logo entra em ação: "Assim como o sal é uma junta de três elementos, fogo, ar e água, assim a república é uma união de três estados, eclesiástico, nobreza e povo" (VIEIRA, 1995, p. 18). Devem se unir em uma mesma causa, mas não serem iguais. Devem se "animar" e deixar de ser o que são por imunidade. Segundo Vieira, “os seculares pagam, e os eclesiásticos dão". Em outro momento afirma: "Não digo que paguem os eclesiásticos, mas digo que deem" (VIEIRA, 1995, p. 22). É algo proibido nos próprios cânones, no entanto, as circunstâncias exigiam isto. “Assim declara Cristo que precede o direito natural ao positivo, e que pode ser lícito, pelas circunstâncias do tempo, o que pelas leis e cânones é proibido" (VIEIRA, 1995, p. 23). É através deste jogo de palavras, com provas baseadas em interpretações do Evangelho, que o orador astuto vai guiando os seus ouvintes a defenderem sua proposta.

Com a nobreza é diferente. Vieira a compara com a água, um dos componentes do sal. Primeiramente um raciocínio lógico: "é justo que os que se sustentam dos bens da coroa não faltem à mesma coroa com seus próprios bens". Assim também fazem as águas: “Tornam os rios perpetuamente ao mar e em tempos tempestuosos com mais pressa e muito tributo". Assim como na tempestade a água corre mais rápido, a nobreza deve contribuir com maior velocidade com suas riquezas para o reino. $\mathrm{Ou}$, assim como a terra recebe a água salgada do mar e a devolve doce, os nobres devem pagar docilmente o tributo, uma situação árdua que exige um ato gentil.

Após formular a lógica do argumento através do conhecimento que tinha sobre a Filosofia da Natureza, o pregador estabelece uma identidade entre a nobreza e o rei D. João IV que acabara de chegar ao trono. Argumenta que "já que a fidalguia de Portugal saiu com a glória de levantar o rei, não deve querer que a leve outrem de o conservar e sustentar no reino". E "quem se gloria da 
Religare, ISSN: 19826605, v.15, n.1, agosto de 2018, p.324-350.

feitura, não deve recusar o peso da conservação". Cita uma passagem bíblica para corroborar sua ideia: “Eu vos criei, e vos susterei”. (Is, 46,4.)

A identidade do povo também é forjada. “Em Lisboa não há povo. Em Lisboa não há mais que dois estados - eclesiástico e nobreza. Vassalos que com tanta liberalidade despendem o que têm, e ainda o que não têm, por seu rei, não é povo". "E povo que oferece com vontade e liberalidade não é povo, é príncipe" (VIEIRA, 1995, p. 30). Deste modo, Vieira vai buscando desenvolver uma identidade entre os portugueses. Vale registrar que a própria figura de Santo Antonio foi usada para dar força a esta criação.

Por sinal, esta seria a principal função da retórica de acordo com o que nos ensina Michel Meyer: "a retórica é a negociação da distância entre os homens a propósito de uma questão, de um problema" (MEYER, 2007, p. 27). Em outro momento diz o autor: “Tudo o que opõe ou reúne os homens, ainda que apenas por um momento, participa desta distância que é o objeto último da retórica" (MEYER, 2007, p. 31). A retórica negocia a distância, e de fato, foi o que Vieira fez. Portanto, o discurso adquire um caráter maniqueísta: "as forças benéficas, por um lado, que são as da convergência, da reunião, da coesão; as forças maléficas, por outro, as da dispersão, do rompimento, da dissociação" (GIRARDET, 1997, p. 160).

Desta maneira, o padre não queria pôr fim à estrutura estamental de sua época. Pelo contrário: “Deixem todos de ser o que eram, para se fazerem o que devem; desfaçam-se todos como devem, tornarão a ser o que eram" (VIEIRA, 1995, p. 31). A ideia aqui era se adaptar às necessidades do momento para a conservação do Estado, e não transformar estruturalmente a sociedade. São argumentos quase-lógicos em que a situação torna-se compatível às passagens bíblicas. A retórica da unidade é referente ao momento e não para promover mudanças aprofundadas, pois quando a poeira abaixasse os estados "tornarão a ser o que eram". 
Religare, ISSN: 19826605, v.15, n.1, agosto de 2018, p.324-350.

\section{Conclusão}

Ao observar a função da retórica no processo de consolidação e legitimação dos Bragança após a Restauração, vem à tona o impacto desta atividade discursiva no mundo político. As estratégias argumentativas que compuseram as propostas e projetos das forças políticas em conflito tornam-se, deste modo, um caminho para se compreender melhor a dinâmica das relações que se estabeleceram. Aparecem como instrumentos indispensáveis nas mãos de exímios oradores que buscavam alcançar resultados específicos que dificilmente seriam atingidos por outros caminhos, como pela ameaça ou pelo pagamento. $^{2}$

O padre Antonio Vieira buscou, através de estratégias retóricas que incluíam o ideal de unidade, promover a sacralização da política instalada no reino de Portugal a partir de 1640. Capturando as aspirações e dialogando com os conflitos da época, assemelhando, por sua vez, o contexto político no qual atuava a passagens bíblicas selecionadas, Vieira procurava consolidar a Restauração e convencer todos os estados a contribuírem para a promoção daquele projeto de poder que levaria D. João IV a liderar o Quinto Império, tornando Lisboa a cabeça do reino de Deus na Terra.

Assim, partindo da premissa de que o absolutismo e o Barroco foram estruturas edificadas por grupos sociais tradicionais da civilização medieval da Europa que queriam se perpetuar no poder, a retórica pode ser vista como um dos instrumentos chaves nessa cultura, na qual o discurso engenhoso tinha uma finalidade prática: desvendar o divino nas coisas do mundo. A cultura do Barroco é uma cultura dedicada à retórica. Desta forma, como pudemos ver, o poder político não se estabelecia apenas pela força, mas pelo investimento nas

\footnotetext{
${ }^{2}$ Aqui se faz uma alusão ao que nos ensina Olivier Reboul sobre "um tipo de persuasão que não se obtém nem pelo dinheiro nem pela ameaça: a que concerne a retórica". (REBOUL, 2004, p. XVI).
} 
Religare, ISSN: 19826605, v.15, n.1, agosto de 2018, p.324-350.

táticas e estratégias de convencimento adequadas aos valores e saberes compartilhados do Portugal dos seiscentos.

\section{Referências}

Aprovação do R. P. M. FR. Cristovão de Almeida. In: VIEIRA. Pe. Antonio. Sermão histórico e panegírico anos da rainha. Lisboa: Oficina de IOAM da Costa, 1668.

ARGAN, Giulio Carlo. La retórica aristotélica y El barroco: El concepto de persuasion como fundamento de La temática figurativa barroca. In: Anales del Instituto de investigaciones estéticas, no 96, p. 111-116, 2010.

BARILLI, Renato. Retórica. Lisboa: Presença, 1979.

BOUZA, Fernando. Imagem y propaganda: capítulos de história cultural Del reinado de Felipe II. Madrid: Akal, 1998.

CAROLINO, Luís Miguel. A ciência e os Topoi retóricos em Antonio Vieira: um caso de difusão cultural em Portugal e no Brasil durante o século XVII. Revista da SBHC, n. 18, p. 55-72, 1997. Disponível em: <http://www.sbhc.org.br/revistahistoria/view?ID_REVISTA_HISTORIA=24>.

Acesso em: 25 jun. 2018.

CIDADE, Hernani. Padre Antônio Vieira. Lisboa: Arcádia, s/d.

COSTA, Leonor Freire; CUNHA, Mafalda Soares da. D. João IV. Lisboa: Circulo de Leitores, 2006.

DE CERTEAU, Michel. A escrita da história. Tradução Maria de Lourdes Menezes. 2. ed. Rio de Janeiro: Forense Universitária, 2008.

DUBY, Georges. O ano mil. Tradução Teresa Matos. Lisboa: Edições 70, 1967.

FOUCAULT, Michel. As palavras e as coisas: uma arqueologia das ciências humanas. Tradução Salama Tannus Muchail. 5. ed. São Paulo: Martins Fontes, 1990.

GIRARDET, Raoul. Mitos e mitologias políticas. Tradução Maria Lucia Machado. São Paulo: Cia das Letras, 1997.

HANSEN, João Adolfo. Alegoria: construção e interpretação da metáfora. São Paulo: Hedra; Campinas: Unicamp, 2006.

LISBOA, João Francisco. Vida do padre Antonio Vieira. Rio de Janeiro: W. M. Jackson INC., s/d.

LOPEZ, Ana Isabel. Poder y ortodoxia: el gobierno del Santo Oficio en el Portugal de los Austrias (1578-1653). Tese (Doutorado em História). Universidad de Castilla, 2008.

MAGALHÃES, Leandro Henrique. Padre Antonio Vieira e a economia portuguesa na época da restauração. Revista de História Regional, v. 11, n. 1, p. 87-107, 2006. Disponível em: $<$ http://www.revistas2.uepg.br/index.php/rhr/article/view/2224/1705> Acesso em: 23 jun. 2018. 
Religare, ISSN: 19826605, v.15, n.1, agosto de 2018, p.324-350.

MALEVAL, Maria do Amparo Tavares. Fernão Lopes e a retórica medieval. Niterói: EdUFF, 2010.

MARAVALL, José Antonio. A cultura do barroco: análise de uma estrutura histórica. Tradução Silvana Garcia. São Paulo: EDUSP, 2009.

MARQUES, João Francisco. A parenética portuguesa e a Restauração (1640-1668): a revolta e a mentalidade. Tese (Doutorado em História). Porto: Instituto Nacional de Investigação Científica, 1983.

MENDES, Margarida Vieira. A oratória barroca de Vieira. Lisboa: Caminho, 1989.

MEYER, Michel. Questões de retórica: linguagem, razão e sedução. Tradução António Hall. Lisboa: Edições 70, 2007.

MOTT, Luiz. Santo Antônio, o divino capitão-do-mato. In: REIS, João José; GOMES, Flávio dos Santos. (Orgs.). Liberdade por um fio: história dos quilombos no Brasil. São Paulo: Cia das Letras, 1996. p. 110-138.

MURARO, Valmir Francisco. Padre Antônio Vieira: retórica e utopia. Florianópolis: Insular, 2003.

PARKER, Geoffrey. David o Goliat: Felipe II y su mundo en la década de 1580. In: KAGAN, Richard L; PARKER, Geoffrey (eds.) España, Europa y el mundo Atlântico. Madrid: Marcial Pons, 2002. p. 321-346.

PÉCORA, Alcir. Sermões: o modelo sacramental. In: VIEIRA, Antonio. Sermões. Tomo I. São Paulo: Hedra, 2000. p. 11-25.

PLATIN, Michel. A argumentação: história, teorias e perspectivas. Tradução Marcos Marcionilo. São Paulo: Parábola, 2008.

REBOUL, Olivier. Introdução à retórica. Tradução Ivone Castilho Benedetti. São Paulo: Martins Fonte, 2004.

SARAIVA, Antonio J. O discurso engenhoso: estudos sobre Vieira e outros autores barrocos. São Paulo: Perspectiva, 1980.

SCHAUB, Jean-Frédéric. Portugal na monarquia hispânica (1580-1640). Tradução Isabel Cardeal. Lisboa: Livros Horizontes, 2001.

SKINNER, Quentin. As fundações do pensamento político moderno. Tradução Renato Janine Ribeiro. São Paulo: Cia das Letras, 1996.

VIEIRA, Pe. Antonio. Sermão da Segunda Dominga da Quaresma. In:

Sermões. Erechim: Edelbra, 1998a. Disponível em: $<$ http://www.literaturabrasileira.ufsc.br/documentos/?action=download\&id=366 79\#_ftnref29>. Acesso em: 06 jan. 2014.

VIEIRA, Pe. Antonio. Sermão da Quarta Dominga da Quaresma. In:

Sermões. Vol. II. Erechim: Edelbra, 1998b. Disponível em: $<$ http://www.literaturabrasileira.ufsc.br/documentos/?action=download\&id=366 65>. Acesso em: 15 ago. 2015.

VIEIRA, Pe. Antonio. Sermão da Sexagésima. In: Sermões. Erechim: Edelbra, 1998c. Disponível em: $<$ http://www.literaturabrasileira.ufsc.br/documentos/?action=download\&id=366 84>. Acesso em: 06 jan. 2014.

VIEIRA, Pe. Antonio. Sermão de Santo Antonio. In: Escritos histórico e políticos. São Paulo: Martins Fontes, 1995. p. 3-33. 
Religare, ISSN: 19826605, v.15, n.1, agosto de 2018, p.324-350.

VIEIRA, Pe. Antonio. Sermão de São Roque. In: . Sermões. Vol II. Erechim: Edelbra, 1998d. Disponível em: $<$ http://www.literaturabrasileira.ufsc.br/documentos/?action=download\&id=367 17>. Acesso em: 15 ago. 2015.

VIEIRA. Pe. Antonio. Sermão histórico e panegírico anos da rainha. Lisboa: Oficina de IOAM da Costa, 1668. 